\title{
The effect of mesenchymal stromal cells of various origins on mortality and neurologic deficit in acute cerebral ischemia-reperfusion in rats
}

\author{
Konovalov S. ${ }^{1}$, Moroz V. ${ }^{1}$, Konovalova N. ${ }^{1}$, Deryabina O. ${ }^{2,3}$, Shuvalova N. ${ }^{2}$, Toporova O. ${ }^{2,3}$, Tochylovsky A. ${ }^{4}$, Kordium V., ${ }^{2,3}$ \\ ${ }^{1}$ National Pirogov Memorial Medical University, Vinnytsya, Ukraine \\ ${ }^{2}$ State Institute of Genetic and Regenerative Medicine, National Academy of Medical Sciences of Ukraine, Kyiv, Ukraine \\ ${ }^{3}$ Institute of Molecular Biology and Genetics, National Academy of Sciences of Ukraine, Kyiv, Ukraine \\ ${ }^{4}$ BioTexCom LLC, Kyiv, Ukraine \\ Corresponding author’s e-mail: oderyabina@gmail.com
}

\section{ABSTRACT}

Stroke is a global epidemic issue and the second leading cause of death in the world and in Ukraine. According to official statistics, every year 100-110 thousand Ukrainians suffer acute cerebrovascular disorders. One third of such patients are of working age, up to $50 \%$ will have a disability, and only one in ten will fully return to full life. So far, promising experimental data on the treatment of neurological dysfunction using mesenchymal stromal cells (MSCs) have been obtained.

THE AIM OF STUDY is to compare the effect of MSCS of different origins on mortality and neurologic deficit in rats with acute cerebral ischemiareperfusion injury (CIRI).

MATERIALS AND METHODS. Acute cerebral ischemia-reperfusion was modeled by transient bilateral 20-minute occlusion of internal carotid arteries in male Wistar rats aged 4 months. Animals were injected intravenously with $1 \cdot 10^{6} \mathrm{MSC}$ s derived from human umbilical cord Wharton'sjelly (hWJ-MSC), human and rat adipose tissue. Other groups of experimental animals were injected intravenously with rat fetal fibroblasts and cell lysate from hWJ-MSC. The last group of rats received Citicoline at a dose of $250 \mathrm{mg} / \mathrm{kg}$ as a reference drug. Control animals were injected intravenously with normal saline. The cerebroprotective effect of therapy was assessed by mortality and neurologic deficit in rats on the McGraw's stroke index score.

RESULTS. After 12 hours of observation in the crucial period in the development of experimental acute cerebrovascular disorders with the administration of hWJ-MSC, mortality was only $10 \%$ against $45 \%$ of animals in the control group. The use of rat fetal fibroblasts reduced the mortality of animals compared to the control group by an average of $25 \%$. CIRI in rats caused severe neurologic deficits: paralysis, paresis, ptosis, circling behavior. On the $7^{\text {th }}$ day of observation in the control group of animals, the mean score on the McGraw's stroke index indicated severe neurological disorders. On the $14^{\text {th }}$ day of observation in this group of animals there was no complete recovery of lost central nervous system functions. Compared with the control group of animals, all the treatment agents for acute CIRI (MSCs of various origins, MSC's lysate and Citicoline) contributed to a significant regression of neurologic deficit.

CONCLUSIONS. Thus, transplantation of human Wharton's jelly-derived MSCs and rat fetal fibroblasts reduced mortality and alleviated neurological symptoms in rats with experimental ischemic stroke. hWJ-MSC, rat fetal fibroblasts, and rat adipose-derived MSCs reduced the incidence of neurological disorders better than Citicoline, which was accompanied by a regression of neurologic deficit dynamics on the $14^{\text {th }}$ day of follow-up. The ability of stem cells of different origins to reduce neurologic deficit indicates the feasibility of their use in experimental acute cerebral ischemia.

KEY WORDS: ischemic stroke; cerebral ischemia-reperfusion injury; neurologic deficit; mesenchymal stromal cells; cell lysate; Citicoline

Stroke is a global epidemic and the second leading cause of death in the world and Ukraine [1, 2]. According to official statistics, every year
100-110 thousand Ukrainians develop acute cerebrovascular disorders. One third of such patients are of working age, up to $50 \%$ will have a dis- 
ability, and only one in ten will fully return to normal life [2]. Therefore, medical care in acute cerebrovascular disorders is a priority in the Program of medical guarantees with funding at a higher rate [3].

In the treatment of stroke, it is important to restore perfusion of the ischemic area as soon as possible $[4,5]$. However, the search for effective and safe means to reduce the manifestations of acute cerebrovascular disorders is still ongoing.

So far, promising experimental data on the treatment of neurological dysfunction using mesenchymal stromal cells (MSCs) have been obtained [6-9]. It should be noted that MSCs are multipotent cells that have unlimited ability to grow, divide and even differentiate in vitro into neurons, astrocytes and oligodendrocytes [10-12]. In vivo MSCs in the cerebral infarction model in rats have also been shown to improve neurological function [12]. However, comparative studies for different types of MSCs in cerebrovascular diseases model have been described little.

The AIM of our study was to compare the effect of MSCs of different origins on mortality and neurologic deficits in rats with acute cerebral ischemia-reperfusion injury (CIRI).

\section{MATERIALS AND METHODS}

For the experiment, we used 200 adult 4-month-old albino Wistar rats weighting 160-190 g. Animals were kept under standard conditions with water and food ad libitum in the vivarium of M. I. Pirogov Vinnytsia National Medical University. The study followed the guidelines of the State Expert Center of the Ministry of Health of Ukraine and national requirements "General Ethical Principles of Animal Experiments", approved by the First National Congress on Bioethics (Kyiv, Ukraine, 2001) as well as the Law of Ukraine "On Protection of Animals from Cruelty" (dated 26.02.2006).

Cerebral ischemia-reperfusion injury model. An experimental CIRI was modeled by bilateral ligation of the internal carotid arteries for 20 minutes under anesthesia with Propofol-Novo $60 \mathrm{mg} / \mathrm{kg}$ (NovopharmBiosynthesis LLC, Ukraine). The selected model reflects the clinical picture of cerebral stroke and is adequate for the experimental study of potential neuroprotective agents [13]. MSCs of various origins in the amount of $1 \cdot 10^{6}$ cells per animal in $0.2 \mathrm{~mL}$ of $0.9 \% \mathrm{NaCl}$ solution were injected once intravenously into the catheterized femoral vein immediately after CIRI. Immediate administration was performed to assess the potential of MSCs to prevent the progression of acute ischemic injury, namely the area of ischemic tissue "penumbra", which is the main target of ischemic stroke therapy in the first hours and days after the onset of the disease. The effectiveness of the treatment of acute cerebral ischemia was determined by the dynamics of rat mortality and neurologic deficit.

The isolation of human MSCs from umbilical cord-derived Wharton's jelly. After an informed consent, umbilical cord was obtained in aseptic conditions from a healthy woman during a normal delivery at 39 weeks of pregnancy. All experiments were performed on a sample from one umbilical cord.

The tissue was delivered to the laboratory in DMEM medium (BioWest, Austria), with antibiotics (penicillin $100 \mathrm{IU} / \mathrm{mL}$, streptomycin 100 $\mu \mathrm{g} / \mathrm{mL}$ ) and processed no later than 8 hours after the labor. The umbilical cord was washed from the blood as much as possible, placed in a new medium for 20-30 minutes with a 10-fold concentration of penicillin $1000 \mathrm{IU} / \mathrm{mL}$, streptomycin $1000 \mu \mathrm{g} / \mathrm{mL}$ (Kyivmedpreparat, Ukraine) and antifungal amphotericin B $50 \mathrm{IU} / \mathrm{mL}$ (Biowest, France). All manipulations were performed under sterile conditions. Vessels (a vein and two arteries) were removed from the umbilical cord. Umbilical cord Wharton's jelly was isolated, minced with scissors to the pieces up to $0.1-0.5 \mathrm{~cm}$ and resuspended in warm $\left(37^{\circ} \mathrm{C}\right)$ growth medium alpha-MEM (BioWest, Austria), supplemented with $10 \%$ fetal bovine serum (HyClone, USA) $2 \mathrm{mM}$ L-glutamine (Sigma, USA) and $10 \mathrm{nM}$ fibroblast growth factor-1 (Interpharm Biotek, Ukraine). The cultivation was performed in a $25 \mathrm{~cm}^{2}$ or $75 \mathrm{~cm}^{2}$ culture flask (Bioswisstec, Switzerland) in a $\mathrm{CO}_{2}$ incubator at $37^{\circ} \mathrm{C}$ and $5 \% \mathrm{CO}_{2}$ by explant technique. After 7-14 days, the first clones were obtained from the explants, which were grown to $80 \%$ monolayer.
The medium was changed every 3 days. Solutions of $0.02 \%$ Versen and $0.25 \%$ trypsin (Biowest, France) in a ratio of 1:1 were used for cell subculture according to standard methods. Cells were seeded at $5 \cdot 10^{3}$ cells per $\mathrm{cm}^{2}$, expanded to the $2^{\text {nd }}$ passage and characterized by morphology and surface markers [14] before further administration to experimental animals.

The isolation of human adipose-derived MSCs. We use standard method with modification to obtain adipose-derived MSCs [15]. After signing an informed consent, adipose tissue was obtained from 23-33 year-old women during cosmetic liposuction from the abdominal fat. All experiments were performed with the sample of one liposuction.

Within 2 hours after the surgery, the material was delivered to the laboratory and immediately processed to isolate MSCs. $25 \mathrm{~mL}$ of fat was centrifuged for $10 \mathrm{~min}$ at $800 \mathrm{xg}$ at room temperature to separate from blood. Then it was washed twice by centrifugation with phosphate buffer saline (PBS) (Sigma, USA) in a ratio 1:1. An equal volume of $0.2 \%$ solution of collagenase type I (Gibco, USA) in PBS heated to $37^{\circ} \mathrm{C}$ was added to the washed adipose tissue. The resulting mixture was shaken on a shaker for $1 \mathrm{~h}$ at $37^{\circ} \mathrm{C}$, and then centrifuged at room temperature for $10 \mathrm{~min}$ at $800 \mathrm{xg}$. Mature adipose cells on top and most of the fluid were discarded, leaving about $5 \mathrm{~mL}$ of cell pellet. The obtained pellet was resuspended in $20 \mathrm{~mL}$ of nutrient medium DMEM/F12 (BioWest, Austria), supplemented with $10 \%$ fetal calf serum with antibiotics, and seeded into $25 \mathrm{~cm}^{2}$ culture flasks in a volume of $5 \mathrm{~mL}$. After $24 \mathrm{~h}$, the nutrient medium was changed discarding non-adherent cells. Subsequently, the medium was changed every 3 days. When $70-80 \%$ of the monolayer was reached, the first cell subculture was performed using a mixture of $0.25 \%$ trypsin solution and $0.02 \%$ Versene solution in a ratio of $1: 1$ according to standard methods. The seeding density was $5 \cdot 10^{3} \mathrm{cell} / \mathrm{s} / \mathrm{cm}^{2}$. Cells were expanded to the $2^{\text {nd }}$ passage.

Umbilical cord and adipose-derived MSCs at the second passage were stained with hematoxylin and eosin to check their morphology, and also analyzed by flow cytometry using cell sorter FACSAria (BD Biosciences, USA). Cell phenotyping for the surface markers CD73, CD90, CD105, CD34 and CD45 were performed according to the standard procedure using anti-CD105 PerCP-Cy5.5 (cat. \#560819), anti-CD90 PerCP-Cy5.5 (cat. \#561557), anti-CD73 PerCP-Cy ${ }^{\mathrm{TM}} 5.5$ (cat. \#561260), anti-CD34 APC (cat. \#345804), anti-CD45 FITC (cat. \#345808) mouse anti-human monoclonal antibodies (all - BD Bioscience, USA) [14]. The multipotent potential of cells was confirmed by directed differentiation into adipo-, chondro- and osteogenic direction using the STEMPRO ${ }^{\circledR}$ Adipogenesis Differentiation Kit, STEMPRO ${ }^{\circledR}$ Chondrogenesis Differentiation Kit and STEMPRO ${ }^{\circledR}$ Osteogenesis Differentiation Kit (Thermo Fisher Scientific, USA), according to the instructions of manufacturer (data not presented). These analyses confirmed belonging of isolated cells to MSCs according to minimal criteria.

The isolation of rat adipose-derived MSCs. MSCs from rat adipose tissue were isolated according to standard protocol with some modifications [16]. Abdominal adipose tissue of rats was obtained in the amount of $2 \mathrm{~g}$. The experiment used sample from one animal euthanized with a 10-fold overdose of sodium thiopental at $50 \mathrm{mg} / \mathrm{kg}$ (Brovarpharma, Ukraine). The adipose tissue was washed twice by centrifugation with PBS, and then added an equal volume of $0.2 \%$ solution of collagenase type I heated to $37^{\circ} \mathrm{C}$ in PBS. Subsequent phenotyping were performed as described for human adipose-derived MSCs, using mouse anti-rat antibodies antiCD45 FITC (cat. \#554883, BD Pharmingen ${ }^{T M}$, USA), anti-CD90 PE (cat. \#551401, BD Pharmingen ${ }^{T M}$, USA), anti-CD34 FITC (cat. \#11-0341-82, Invitrogen, USA), anti-CD105 FITC (cat. \#MA1-19594, Invitrogen, USA).

The isolation of rat embryonic fibroblasts. The study used the muscle tissue of four 15-day-old rat embryos; the gestation period was determined by the copulation plug. The female was euthanized with sodium thiopental $50 \mathrm{mg} / \mathrm{kg}$. The tissue was kept for $20 \mathrm{~min}$ in DMEM medium with 10-fold concentration of antibiotics (penicillin $1000 \mathrm{IU} / \mathrm{mL}$ and streptomycin $1000 \mu \mathrm{g} / \mathrm{mL}$ ), then placed in $0.25 \%$ solution of a mixture of trypsin and $0.02 \%$ Versen in a ratio of $1: 1$ and kept at $37{ }^{\circ} \mathrm{C}$ overnight In the morning, the fluid was discarded, $10 \mathrm{~mL}$ of serum-free DMEM 
medium was added to the tissue and pipetted to obtain a homogeneous cell suspension. Then fetal bovine serum up to $10 \%$ was added and the suspension was seeded in Petri dishes. After 24-48 h, a monolayer of cells was formed and detached from the plastic substrate using a mixture of trypsin $0.25 \%$ and Versen $0.02 \%$ in a ratio of $1: 1$ for further use in the experiment [17]. Cells were identified by spindle-shaped morphology and hematoxylin-eosin staining.

The obtaining of MSC's lysate. Wharton's jelly-derived cells at the $80-90 \%$ monolayer density were detached from substrate, centrifuged, counted, diluted with DMEM medium to the concentration of $1 \cdot 10^{6} / \mathrm{mL}$ and aliquoted in $1 \mathrm{~mL}$. On an ultrasonic disintegrator Ultrasound-2T (Sumy, Ukraine), the cells were subjected to ultrasound disintegration for $10 \mathrm{~s}$ with a power of $22 \mathrm{kHz}$, then centrifuged for $10 \mathrm{~min}$ at $12,000 \mathrm{xg}$. The supernatant was collected and used in further experiments.

Study design. Experimental animals were divided into 8 groups (Table 1).

Group 1 is sham-operated rats, which were successively subjected to the following interventions (anesthesia, skin incision, vascular isolation) except for internal carotid artery ligation, which reproduced the effects of traumatic experimental conditions. Group 2 is a control group. The rats in this group underwent 20-minute cerebral ischemia by internal carotid artery ligation. After $20 \mathrm{~min}$, the ligatures were removed from the arteries (reperfusion) and a single dose of $0.9 \%$ normal saline was injected into the femoral vein at a dose of $2 \mathrm{~mL} / \mathrm{kg}$. A similar dose was administered to rats of Group 1. Group 3 animals were once transplanted with human Wharton's jelly-derived MSCs at a dose of $1 \cdot 10^{6}$ cells per animal. Group 4 underwent a single transplantation of human adipose-derived MSCs at a dose of $1 \cdot 10^{6}$ cells/animal. Group 5 received $1 \cdot 10^{6}$ cells/animal of rat fetal fibroblasts. Group 6 received $1 \cdot 10^{6}$ cells/animal of rat adiposederived stem cells. Group 7 was administered a single dose of human Wharton's jelly-derived MSC's lysate $(0.2 \mathrm{~mL} /$ animal). Group 8 received a single dose of $250 \mathrm{mg} / \mathrm{kg}$ of reference drug Citicoline (Neuroxon, Arterium Corporation, Ukraine). Citicoline was chosen because of its ability to positively affect the regression of neurologic deficit in the experiment and improve cognitive functions in patients with cerebral ischemia [18-21].

The modified McGraw's stroke index score was chosen for the analysis of neurologic deficit in rats (Table 2) [21]. Studies have been performed on the $7^{\text {th }}$ (subacute period of ischemia) and $14^{\text {th }}$ days (recovery period) $[22,23]$. The severity of the neurologic deficit was assessed by the sum of the corresponding points: up to 2.5 points - mild symptoms (paucity of movements, weakness of the extremities, unilateral semiptosis, tremor, circling behavior); from 3 to 10 points - severe manifestations of neurological disorders (paresis and paralysis of the limbs, lateral position).

Statistical processing of the obtained data was performed using MS Excel 2010 (Microsoft, USA) and Statistics 6.1 software (StatSoft Inc. USA). The reliability of differences was assessed using the nonparametric Mann-Whitney U-test. Data are presented as mean and standard deviation $(\mathrm{M} \pm \sigma)$. The difference between the studied parameters was considered statistically significant at a value of $p<0.05$.

\section{RESULTS AND DISCUSSION}

Experimental cell therapy of acute transient cerebral ischemia-reperfusion in rats using stem cell transplantation of various origins provided the reduce of the mortality rate of experimental animals (Fig. 1).

The greatest protective effect in rats with CIRI was observed when using human Wharton's jelly-derived MSCs (Group 3). At 12 hours of followup as a critical period in the development of experimental acute cerebrovascular disorders the mortality was only $10 \%$ vs. $45 \%$ of shamoperated animals $(p<0.05)$. The use of rat fetal fibroblasts reduced the mortality of animals relative to the control group by an average of $25 \%(p<0.05)$. Compared with the reference drug Citicoline at a dose of $250 \mathrm{mg} / \mathrm{kg}$, the use of MSCs of various origins had no significant differences.
Table 1. The distribution of animals in the experiment.

\begin{tabular}{|c|c|c|}
\hline GROUP & $\begin{array}{l}\text { NUMBER OF } \\
\text { ANIMALS }\end{array}$ & TREATMENT \\
\hline 1 & 10 & $\begin{array}{l}\text { sham-operated animals + normal saline at } \\
\text { a dose of } 2 \mathrm{~mL} / \mathrm{kg}\end{array}$ \\
\hline 2 & 40 & $\mathrm{CIRI}+$ normal saline at a dose of $2 \mathrm{~mL} / \mathrm{kg}$ \\
\hline 3 & 20 & $\begin{array}{l}\text { CIRI + human Wharton's jelly-derived MSCs } \\
\text { at a dose of } 1 \cdot 10^{6} \text { cells/animal }\end{array}$ \\
\hline 4 & 25 & $\begin{array}{l}\text { CIRI + human adipose-derived MSCs } \\
\text { at a dose of } 1 \cdot 10^{6} \text { cells/animal }\end{array}$ \\
\hline 5 & 20 & $\begin{array}{l}\mathrm{CIRI}+\text { fetal rat fibroblasts at a dose } \\
\text { of } 1 \cdot 10^{6} \mathrm{cells} \text { /animal }\end{array}$ \\
\hline 6 & 25 & $\begin{array}{l}\mathrm{CIRI}+\text { rat adipose-derived MSCs at a dose } \\
\text { of } 1 \cdot 10^{6} \text { cells/animal }\end{array}$ \\
\hline 7 & 25 & $\begin{array}{l}\mathrm{CIRI}+\text { Iysate of human Wharton's jelly- } \\
\text { derived MSCs at a dose } 0.2 \mathrm{~mL} / \text { animal }\end{array}$ \\
\hline 8 & 25 & $\mathrm{CIRI}+$ Citicoline at a dose $250 \mathrm{mg} / \mathrm{kg}$ \\
\hline
\end{tabular}

\begin{tabular}{|l|c|c|c|}
\hline \multicolumn{1}{|c|}{ SYMPTOMS } & PoINTS & & $\begin{array}{l}\text { Table 2. Modified } \\
\text { McGraw's stroke index }\end{array}$ \\
\hline Paucity of movements & 0.5 & & $\begin{array}{l}\text { score for neurologic } \\
\text { deficit assessment. }\end{array}$ \\
\hline Tremor & 1 & & \\
\hline Unilateral semiptosis & 1 & \\
\hline Bilateral semiptosis & 1.5 & \\
\hline Leg weakness & 1.5 & \\
\hline Unilateral ptosis & 1.5 & \\
\hline Bilateral ptosis & 1.5 & \\
\hline Circling behavior & 2.0 & \\
\hline Paresis & $2-5$ & $3-6$ \\
\hline Paralysis & 7.0 & \\
\hline Comatose & 10.0 & \\
\hline Fatal case & &
\end{tabular}

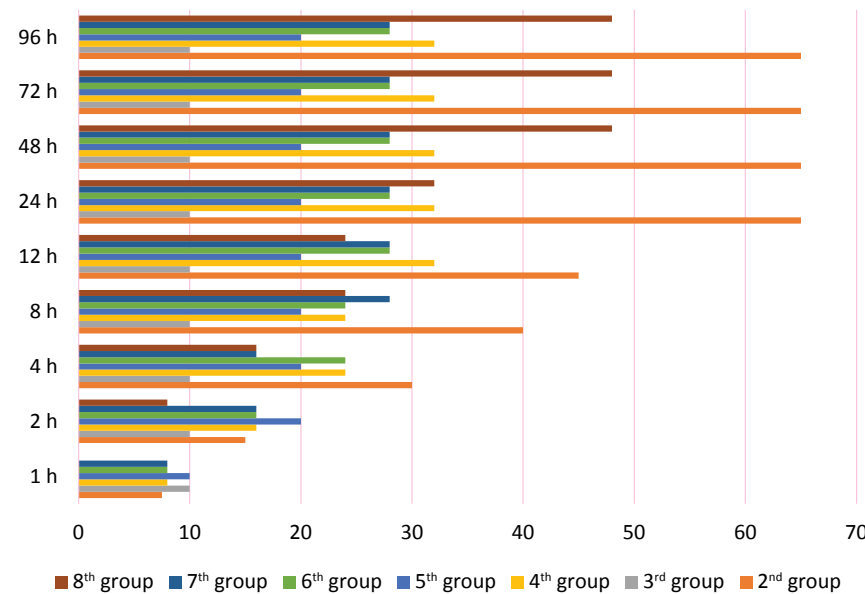

Fig. 1. The mortality rate of rats with transient cerebral ischemia-reperfusion in experimental groups, \%. Data for Group 1 are not presented because all animals survived. 
During the observation period in Group 1 of sham-operated animals no fatalities were recorded. One day after the start of the observation, the mortality of rats with CIRI was significantly lower both in groups with administration of different types of MSCs, cell lysate and Citicoline compared with the control group (Fig. 1). During the following observation (up to the $14^{\text {th }}$ day of the experiment), there was no mortality of rats with CIRI in these groups.

According to the degree of the survival effect in the critical period of $\mathrm{CIRI}(12 \mathrm{~h})$, the studied products can be arranged in the following order: human Wharton's jelly-derived MSCs $>$ rat fetal fibroblasts $>$ Citicoline $>$ rat adipose-derived stem cells $=$ lysate $>$ human adipose-derived stem cells $>$.

For statistical reliability of neurologic deficit assessment, 7 animals of each group were analyzed on the $7^{\text {th }}$ and $14^{\text {th }}$ day of observation. CIRI in rats caused severe neurological disorders: paralysis, paresis, ptosis, circling behavior - (Table 3 ).

On the $7^{\text {th }}$ day of observation in the control group of animals, the mean McGraw's stroke index score indicated severe neurological disorders. On the $14^{\text {th }}$ day of observation in this group of animals there was no complete recovery of lost CNS functions.

Compared to the control Group 2 all treatments for acute CIRI (MSCs of various origins, cell lysate and Citicoline) led to a significant regression of neurologic deficit. The best result was obtained with the use of human Wharton's jelly-derived MSCs (Group 3). Also, the result of the use of human Wharton's jelly-derived MSCs was significantly better compared to the reference drug Citicoline on both the $7^{\text {th }}$ and $14^{\text {th }}$ day of the study.

In general, there are a small number of in vivo studies of human Wharton's jelly-derived MSCs in ischemia models in rats. Wu C. et al. found that intracerebral and intravenous transplantation of human Wharton's jelly-derived MSCs improved neurological function in experimental animals [24]. The study of Toyoshima A. et al. confirmed a significant reduction in rat cerebral infarction, improved neurological function and reduced neuroinflammation in 3 and 5 days after the surgery [25]. Similar results were obtained by Zhang $\mathrm{L}$. et al. on the $7^{\text {th }}$ day after the transplantation of human Wharton's jelly-derived MSCs. The authors confirmed the localization of donor cells in the infarct area histologically, and some cells differentiated into neurons after 35 days [12]. That is, exogenous human Wharton's jelly-derived MSCs transplanted to rats are able to migrate to the ischemic area, survive there and even differentiate into neurons to partially restore the affected motor function.

Thus, untreated acute cerebral ischemia rats had severe neurologic deficit at the corresponding time. Human Wharton's jelly-derived MSCs, rat fetal fibroblasts and rat adipose-derived MSCs better contributed to the regression of neurological disorders than Citicoline and cells from other sources, accompanied by a reduction in neurologic deficit on the $14^{\text {th }}$ day of follow-up.

The ability of stem cells of different origins to reduce neurologic deficit indicates the feasibility of their use in acute cerebral ischemia. According to the literature, the study of the effects of MSCs in the treatment of stroke has been conducted for almost two decades. In preclinical trials,
Table 3. The dynamics of neurologic deficit in rats of experimental groups on the $7^{\text {th }}$ and $14^{\text {th }}$ days after acute cerebral ischemia-reperfusion $(n=7)$.

\begin{tabular}{|c|c|c|}
\hline \multirow{2}{*}{ GROUP } & \multicolumn{2}{|c|}{$\begin{array}{l}\text { NEUROLOGIC DEFICITS, } \\
\text { MCGRAW'S STROKE INDEX SCORE }\end{array}$} \\
\hline & DAY 7 & DAY 14 \\
\hline Group 1 (sham-operated animals) & $0.00 \pm 0.00$ & $0.00 \pm 0.00$ \\
\hline $\begin{array}{l}\text { Group } 2 \\
\text { (CIRI + normal saline) }\end{array}$ & $11.79 \pm 0.48^{\star}$ & $9.14 \pm 0.30^{*}$ \\
\hline $\begin{array}{l}\text { Group } 3 \\
\text { (CIRI + human Wharton's } \\
\text { jelly-derived MSCs) }\end{array}$ & $7.14 \pm 0.19^{* \# \wedge}$ & $4.86 \pm 0.15^{\star \# \wedge}$ \\
\hline $\begin{array}{l}\text { Group } 4 \\
\text { (CIRI + human adipose-derived } \\
\text { MSCs) }\end{array}$ & $8.86 \pm 0.23^{\star \#}$ & $5.71 \pm 0.23^{\star \#}$ \\
\hline $\begin{array}{l}\text { Group } 5 \\
\text { (CIRI + fetal rat fibroblasts) }\end{array}$ & $7.71 \pm 0.28^{\star \# \wedge}$ & $5.14 \pm 0.19^{* \# \wedge}$ \\
\hline $\begin{array}{l}\text { Group } 6 \\
\text { (CIRI + rat adipose-derived MSCs) }\end{array}$ & $8.50 \pm 0.26^{\star \# \wedge}$ & $5.43 \pm 0.14^{* \# \wedge}$ \\
\hline $\begin{array}{l}\text { Group } 7 \\
\text { (CIRI + lysate of human Wharton's } \\
\text { jelly-derived MSCs) }\end{array}$ & $8.57 \pm 0.22^{\star \# \wedge}$ & $5.57 \pm 0.22^{* \#}$ \\
\hline $\begin{array}{l}\text { Group } 8 \\
\text { (CIRI + Citicoline) }\end{array}$ & $9.21 \pm 0.16^{\star \#}$ & $6.14 \pm 0.15^{\star \#}$ \\
\hline $\begin{array}{l}\text { Notes: } \\
\text { * }-p<0.05 \text { compared to the sham-opera } \\
\#-p<0.05 \text { compared to the rats with Cl } \\
\wedge-p<0.05 \text { compared to the treatment }\end{array}$ & $\begin{array}{l}\text { d rats (Group 1); } \\
\text { (Group 2); }\end{array}$ & \\
\hline
\end{tabular}

rats are the most widely used animals to model the cerebral ischemia At the same time, even in recent studies, the main source of MSCs was bone marrow and adipose tissue, and only one study was performed with placental cells, and, as in our case, both allogeneic [25] and xenogeneic [26] cells were used in the studies. No reports on the use of MSC's lysate were found. Interestingly, in recent researches on this issue the effects of MSCs from one source were studied, while we compared the impact of both xenogeneic and allogeneic cells from two sources. The dose of cells used by the researchers was $10^{5}-10^{6}$ cells per animal, which is consistent with our experiment design.

Various authors have shown that MSCs transplantation after ischemic stroke improves brain function [25-27], effectively protects ischemic neurons and restores brain injury [28]. Our data on the survival and development of neurological disorders in animals using MSCs immediately after ischemia/reperfusion are only the first stage of study, the results of biochemical, histological and immunochemical studies will be published later.

\section{CONCLUSION}

\section{Human Wharton's jelly-derived MSCs and fetal rat fibroblasts significantly better than Citicoline contributed to the regression of the neurologic deficit on the $14^{\text {th }}$ day after acute cerebral ischemia-reperfusion.}

2. The potential of stem cells of different origins to reduce neurologic deficit indicates the feasibility of their use in experimental acute cerebral ischemia for preclinical studies of cell therapy.

\section{REFERENCES}

1. Available from: https://www.world-stroke.org/world-stroke-day-campaign/why-stroke-matters/learn-about-stroke

2. Available from: https://phc.org.ua/news/29-zhovtnya-vsesvitniy-den-borotbi-z-insultom 
3. Available from: https://www.kmu.gov.ua/news/stacionarne-likuvannya-gostrogo-mozkovogo-insultu-shcho-zminitsya-u-programi-medichnih-garantij-2021

4. Albers GW, Marks MP, Kemp S, et al. Thrombectomy for stroke at 6 to 16 hours with selection by perfusion imaging. N Engl J Med. 2018; 378:708-718. https:// doi.org/10.1056/NEJMoa1713973

5. Nogueira RG, Jadhav AP, Haussen DC, et al. Thrombectomy 6 to 24 hours after stroke with a mismatch between deficit and infarct. N Engl J Med. 2018; 378:11-21. https://doi.org/10.1056/NEJMoa1706442

6. Cheng T, Yang B, Li D, et al. Wharton's Jelly transplantation improves neurologic function in a rat model of traumatic brain injury. Cell Mol Neurobiol. 2015; 35:6419. https://doi.org/10.1007/s10571-015-0159-9

7. Donders R, Bogie JFJ, Ravanidis $S$, et al. Human Wharton's Jelly-derived stem cells display a distinct immunomodulatory and proregenerative transcriptional signature compared to bone marrow-derived stem cells. Stem Cells Dev 2018; 27:65-84. https://doi.org/10.1089/scd.2017.0029

8. He JQ, Sussman ES, Steinberg GK. Revisiting Stem Cell-Based Clinical Trials for Ischemic Stroke. Front Aging Neurosci. 2020; 12:575990. https://doi.org/10.3389/ fnagi.2020.575990

9. Wu KJ, Yu SJ, Chiang CW, et al. Neuroprotective action of human wharton's jelly-derived mesenchymal stromal cell transplants in a rodent model of stroke. Cell Transplant. 2018; 27:1603-1612. https://doi.org/10.1177/0963689718802754

10. Aggarwal S, Pittenger MF. Human mesenchymal stem cells modulate allogeneic immune cell responses. Blood. 2005; 105(4):1815-1822. https://doi.org/10.1182/ blood-2004-04-1559

11. Tondreau T, Meuleman N, Delforge A, et al. Mesenchymal stem cells derived from CD133-positive cells in mobilized peripheral blood and cord blood: proliferation, Oct4 expression, and plasticity. Stem Cells. 2005; 23(8):1105-12. https://doi.org/10.1634/stemcells.2004-0330

12. Zhang $L$, Wang $L M$, Chen WW, et al. Neural differentiation of human Wharton's jelly-derived mesenchymal stem cells improves the recovery of neurological function after transplantation in ischemic stroke rats. Neural Regen Res. 2017; 12:1103-1110. https://doi.org/10.4103/1673-5374.211189

13. Khodakovskij AA, Marinich LI, Bagauri OV. Features of the formation of post-reperfusion damage to neurons - a characteristic of the «ischemia-reperfusion» model. New directions and prospects for the development of modern cerebroprotective therapy for ischemic stroke. Doctor-graduate student. 2013; 3(58):69-76. [In Russian]

14. Tsymbaliuk VI, Deryabina OG, Shuvalova NS, Maslova 00, Pokholenko laO, Toporova OK, et al. Phenotypical changes and proliferative potential of mesenchymal stem cells from humans Wharton's jelly in the cultivation conditions. Ukr Neurosurg J. 2015; 2:17-24. https://doi.org/10.25305/unj.45290

15. Estes BT, Diekman BO, Gimble JM, Guilak F. Isolation of adipose derived stem cells and their induction to a chondrogenic phenotype. Nat Protoc. 2010; 5(7):12941311. https://doi.org/10.1038/nprot.2010.81

16. Kurzyk A, Debski T. Święszkowski W. Pojda Z. Comparison of adipose stem cells sources from various locations of rat body for their application for seeding on polymer scaffolds. J Biomater Sci Polym Ed. 2019; 30(5):376-397. Available from: https://doi.org/10.1080/09205063.2019.1570433

17. Weber SC, Gratop A, Akanbi S, Rheinlaender C, Sallmon H, Barikbin B, et al. Isolation and culture of fibroblasts, vascular smooth muscle, and endothelial cells from the fetal rat ductus arteriosus. Pediatr Res. 2011; 70(3):236-41. https://doi.org/10.1203/PDR.0b013e318225f748

18. Diederich $K$, Frauenknecht $K$, Minnerup $J$, et al. Citicoline enhances neuroregenerative processes after experimental stroke in rats [published correction appears in Stroke. 2012; 43(11):e169]. Stroke. 2012; 43(7):1931-1940. https://doi.org/10.1161/STROKEAHA.112.654806

19. Bustamante $A$, Giralt $D$, Garcia-Bonilla $L$, et al. Citicoline in pre-clinical animal models of stroke: a meta-analysis shows the optimal neuroprotective profile and the missing steps for jumping into a stroke clinical trial. J Neurochem. 2012; 123(2):217-225. https://doi.org/10.1111/j.1471-4159.2012.07891.x

20. Mehta A, Mahale R, Buddaraju K, et al. Efficacy of Neuroprotective Drugs in Acute Ischemic Stroke: Is It Helpful? Journal of neurosciences in rural practice. 2019; 10(4):576-581. https://doi.org/10.1055/s-0039-1700790

21. McGraw CP. Experimental Cerebral Infarction Effects of Pentobarbital in Mongolian Gerbils. Arch Neurol. 1977; 34(6):334-336. https://doi.org/10.1001/ archneur.1977.00500180028006

22. Lee MC, Jin CY, Kim HS, et al. Stem cell dynamics in an experimental model of stroke. Chonnam Med J. 2011; 47(2):90-98. D0l.org/10.4068/cmi.2011.47.2.90. https://doi.org/10.4068/cmj.2011.47.2.90

23. Ding $D C$, Shyu WC, Chiang MF, et al. Enhancement of neuroplasticity through upregulation of beta1-integrin in human umbilical cord-derived stromal cell implanted stroke model. Neurobiol Dis. 2007; 27:339-53. https://doi.org/10.1016/j.nbd.2007.06.010

24. Wu CJ, Wang ZY, Yang YX, Luan Z. Long-term effect of oligodendrocyte precursor cell transplantation on a rat model of white matter injury in the preterm infant. Zhongguo Dang Dai Er Ke Za Zhi. 2017; 19(9):1003-1007. https://doi.org/10.7499/j.issn.1008-8830.2017.09.01

25. Toyoshima A, Yasuhara T, Kameda M, Morimoto J, Takeuchi H, Wang F. Intra-arterial transplantation of allogeneic mesenchymal stem cells mounts neuroprotective effects in a transient ischemic stroke model in rats: analyses of therapeutic time window and its mechanisms. PLoS One. 2015; 10:e0127302. https://doi. org/10.1371/journal.pone.0127302

26. Moisan A, Favre I, Rome C, De Fraipont F, Grillon E, Coquery N. Intravenous injection of clinical grade human MSCs after experimental stroke: functional benefit and microvascular effect. Cell Transplant. 2016; 25:2157-2171. https://doi.org/10.3727/096368916X691132

27. Hu Y, Chen $W$, Wu L, Jiang L, Qin H, Tang N. Hypoxic preconditioning improves the survival and neural effects of transplanted mesenchymal stem cells via CXCL12/ CXCR4 signalling in a rat model of cerebral infarction. Cell Biochem. Funct. 2019; 37:504-515. https://doi.org/10.1002/cbf.3423

28. Son JW, Park J, Kim YE, Ha J, Park DW, Chang MS. Glia-like cells from late-passage human MSCs protect against ischemic stroke through IGFBP-4. Mol Neurobiol. 2019; 56:7617-7630. https://doi.org/10.1007/s12035-019-1629-8

(aRTILL ON THE SITE




\title{
Вплив мезенхімальних стромальних клітин різного походження на летальність та неврологічний дефіцит при гострій ішемії-реперфузії головного мозку у щурів
}

\author{
Мороз В. М. ${ }^{1}$, Коновалов С. В. ${ }^{1}$, Коновалова Н. В. ${ }^{1}$, Дерябіна О. Г. ${ }^{2,3}$, Шувалова Н. С. ${ }^{2}$, \\ Топорова О. К..$^{2,3}$, Точиловський А. А. ${ }^{4}$, Кордюм В. А.,3 \\ ${ }^{1}$ Вінницький національний медичний університет ім. М. І. Пирогова, Вінниия, Україна \\ ${ }^{2}$ ДУ «Інститут генетичної та регенеративної медицини Національної академії медичних наук України», Київ, Україна \\ ${ }^{3}$ Інститут молекулярної біології і генетики Національної академії наук України, Київ, Україна \\ ${ }^{4} \mathrm{TOB} «$ ВіоТехСом», Київ, Україна
}

\section{PE3ЮME}

Інсульт - це глобальна епідемія і друга причина смертності населення у світі та в Україні. За офріційною статистикою щорічно у 100-110 тис. українців розвивається гостре порушення мозкового кровообігу. Третина таких хворих - це особи працездатного віку, до $50 \%$ матимуть інвалідність, і лише кожен десятий повністю повернеться до повноцінного життя. Наразі отримано багатообіцяючі експериментальні дані щодо усунення неврологічної дисфункції при використанні мезенхімальних стромальних клітин (МСК).

META - порівняти вплив МСК різного походження на летальність та неврологічний дефріцит у щурів при гострій ішемії-реперфузії (IP) головного мозКу.

МАТЕРІАЛИ ТА МЕТОДИ. Самцям щурів Вістар віком 4 міс. моделювали гостру ішемію-реперфузію головного мозку шляхом двобічної 20-хвилинної оклюзії внутрішніх сонних артерій та внутрішньовенно вводили МСК, отримані з Вартонових драглів пуповини людини, з жирової тканини людини та щура в дозі $1 \cdot 10^{6}$ клітин. Іншим групам піддослідних тварин в/в вводили сретальні фрібробласти щура та лізат з культури клітин Вартонових драглів пуповини людини. Остання група щурів отримувала однократно рефреренс-препарат цитиколін у дозі 250 мг/кг. Контрольним тваринам в/в вводили фрізіологічний розчин. Оцінку церебропротекторного ефректу терапії проводили за показниками летальності та неврологічного дефіциту у щурів за шкалою McGraw’s stroke-index.

РЕЗУЛЬТАТИ. Через 12 годин спостереження в критичний період у розвитку експериментального гострого порушення мозкового кровообігу при введенні МСК з Вартонових драглів пуповини людини смертність склала лише 10 \% проти 45 \% тварин контрольної групи. Застосування фетальних фрібробластів щура зменшувало летальність тварин відносно контрольної групи в середньому на $25 \%$. IP у щурів викликала тяжкі неврологічні зміни: паралічі, парези, птоз, манежні рухи. На 7-му добу спостереження у контрольній групі тварин середній бал за шкалою McGraw's stroke-index свідчив про важкі неврологічні порушення. На 14-ту добу спостереження в цій групі тварин не відбулося повного відновлення втрачених функцій ЦНС. В порівнянні з контрольною групою тварин усі обрані для дослідження варіанти лікування гострої IP (МСК різного походження, лізат та цитиколін) сприяли достовірному регресу неврологічного десріциту.

Висновки. Таким чином, трансплантація МСК, отриманих із Вартонових драглів пуповини людини, та фретальних фрібробластів щура знижувала летальність, полегшувала неврологічну симптоматику у щурів із експериментальним ішемічним інсультом. МСК Вартонових драглів пуповини людини, фетальні фібробласти та МСК жирової тканини щура краще за цитиколін сприяли зменшенню проявів неврологічних порушень, що супроводжувалось регресом динаміки неврологічного дефріциту на 14-ту добу спостереження. Спроможність стовбурових клітин різного походження зменшувати неврологічний дефріцит свідчить про доцільність їх застосування в умовах експериментальної гострої ішемії головного мозку при доклінічних дослідженнях ефеккивності клітинної терапії.

КЛЮчовІ СловА: ішемічний інсульт; церебральна ішемія-реперфузія; неврологічний десріцит; мезенхімальні стромальні клітини; лізат клітин; цитиколін 